\title{
Patent disputes could trip up genome wide scans for disease
}

The much-awaited \$1,000 genome sequence may never arrive on the market if the owners of patents on disease-related genes have their way. With an estimated $20 \%$ of human genes patented, the so-called 'patent thicket' could hinder the advancement of diagnostics that rely on multiple genes, genome-wide scans or whole genome sequences.

To avoid a potential deadlock, a US committee on gene-based diagnostics proposed last month to redefine the patent system so that anyone developing tests be exempted from infringement liability. However, three of the 18 members of the US Health and Human Services Secretary's Advisory Committee on Genetics, Health and Society dissented, calling the move a "risky intrusion" on the turf of the US patent office, judicial system and Congress.

To be sure, the diagnostics industry is also divided over whether gene patents are the best strategy for continued growth and innovation. "We pride ourselves on being consensus building, but people are strongly in different camps," says Elizabeth Schwinn, spokesperson of the Personalized Medicine Coalition in Washington, DC, which includes diagnostic companies, universities and drug makers.

Even before the 5 February proposal, companies that directly offer consumers genome-wide diagnostics that look for small variations across a person's entire DNA have been on a collision course with those offering clinically validated tests for specific diseases, which typically sequence the entire gene or genes they have exclusive rights to. For example, personal genomics company 23andMe in Mountain View, California offers $\$ 500$ tests that assess risk for more than 100 diseasesincluding mutations in BRCA1 and BRCA2, two breast cancer-related genes for which Salt Lake City, Utah-based Myriad Genetics holds the exclusive license.

"23andMe is almost certainly infringing on Myriad patents_-at least as granted," says Robert Cook-Deegan, a physician and director of the Duke Institute for Genome Sciences \& Policy's Center for Genome Ethics, Law \& Policy in Durham, North Carolina. "But who knows how they would be interpreted in court?" 23andMe declined to comment regarding their gene patent licensing policy.

Until now, there hasn't been enough money in diagnostics to litigate gene patent claims, which would establish a precedent, says Christopher Holman, a biologist and lawyer at the University of Missouri-Kansas City School of Law. "There's practically no case law." In 2003, for instance, a dispute over access to gene tests developed by the Miami Children's Hospital Research Institute for Canavan disease, an inherited metabolic disorder, was settled out of court.

One notable exception is the lawsuit filed last year by the American Civil Liberties Union, which calls into question the constitutionality and validity of Myriad's broad claims on the breast cancer-related genes. In February, the federal judge in that case heard oral arguments from both sides to consider whether the case should go to trial or be dismissed in favor of one party.

In the face of legal uncertainty, personal genomics companies have been mulling over their own licensing strategies for the future. Foster City, California-based Navigenics, which includes an indirect test of the patented Alzheimer's gene APOE, has proposed a royalty-based model that reflects the relative contribution of the licensed gene or single nucleotide polymorphism to the overall value of the service. The company envisions stacking royalties such that they do not exceed $5 \%$ of their sales. But Worcester, Massachusetts-based Athena Diagnostics, which has exclusive rights to the patent for $A P O E$, says it has not come to any conclusions regarding such opportunities.

Other personal genomics companies are watching and waiting for the outcome of the Myriad lawsuit. Newly launched Counsyl of Stanford, California, which, for $\$ 350$, offers prenatal screening for more than 100 diseaserelated genes, including the one related to Canavan disease, does not agree with the Navigenics model. Balaji S. Srinivasan, Counsyl's chief technology officer, says that, in the long run, makers of gene chips and sequencing equipment are an "unstoppable force" that will open the genome to all. "Are people going to have to pay companies to basically look in the mirror?" he asks. "That's something that strikes a lot of people as being fundamentally unfair."

Brendan Borrell, New York

\section{Industry's influence in biologics legislation examined}

How long should developers of complex biologic drugs be able to sell their products without generic competition? It is a question that has plagued US lawmakers, but one that many agree should not be determined by industry maneuvering.

As Nature Medicine went to press, both the Senate and House versions of the health care reform bill provided 12 years of data exclusivity for these branded 'biologics'-protein therapies produced by cultured cells-to help companies recoup research investments. But President Obama and many of his congressional allies have fought for a shorter period of market protection.

In a paper published in December, Donald Light, a health policy expert at the University of Medicine and Dentistry of
New Jersey in Stratford, and his coauthors describe heavy industry influence in determining biologics legislation. Light and his colleagues pored over numerous reports and conducted 16 interviews with key stakeholders to investigate the political route by which the EU established an exclusivity period of ten years beginning in 2004. They concluded that the European Commission's Directorate General for Enterprise crafted the legislation behind closed doors with the help of industry lobbyists, despite vocal opposition from generics companies, consumer groups and member states and without sufficient data showing that the price protection would spur innovation (J. Health Polit. Policy Law 34, 979-1010, 2009).

"This legislation and the lobbying behind it only served to enhance the profits of pharmaceutical companies without any evidence that they benefit patients or society," Light says.

Jack Calfee, a health economist at the American Enterprise Institute, a conservative think tank in Washington, DC, suspects that the authors "are exaggerating the degree to which industry influenced the discussions" in the European legislature. But even if one accepts the study's findings, he says, the same situation is unlikely to happen across the Atlantic where the US Department of Commerce - the nearest equivalent to the Directorate General for Enterprise-wields far less executive power.

"What they do over there is so different from what's done here," Calfee says. "Over here, exclusivity is going to be determined by Congress-there's no doubt about that."

Elie Dolgin, New York 